\title{
The role of Zambian civil society in evaluation
}

\section{John T. Njovu}

Without active civil society and their evaluations, Zambia would still be a colonised nation. It is the welfare societies and cultural groups of indigenous Africans that were the foundation for the political movements that fought for its independence from the British. After political independence, civil society grew because of the 1970 s global oil and financial crises. This was to mitigate the adverse effects on ordinary citizens of the conditionality of borrowing from the World Bank, the International Monetary Fund, and developed nations. The increase in foreign development assistance led to an increase in development projects and programmes along with their associated internal management requirements for monitoring and evaluation (M\&E). Government, during this time, also started to formulate plans and programmes that required components of M\&E (for example, poverty reduction strategies). After the 2005 Paris Declaration on Aid Effectiveness, M\&E rose to prominence in Zambia's national development processes.

Civil society played a major role in the return to multi-party democracy politics of Zambia in 1991. Post 1991, it began to also play a 
major role in $M \& E$ governance and ensuring that the democratic gains of 1991 were protected. Part of the demand for external M\&E capacity development was to enhance its watchdog role over the Zambian government. Though the government recognises civil society as a partner in national democratic processes, it is sometimes mistrustful and hostile to evaluation revelations that are critical of government. There remains a need to strengthen this partnership to ensure that national evaluation capacities are developed. Improved capacities will in turn lead to good governance and public service delivery in Zambia. In this way, sustainable development goals will be attained, and no one will be left behind.

\section{Introduction}

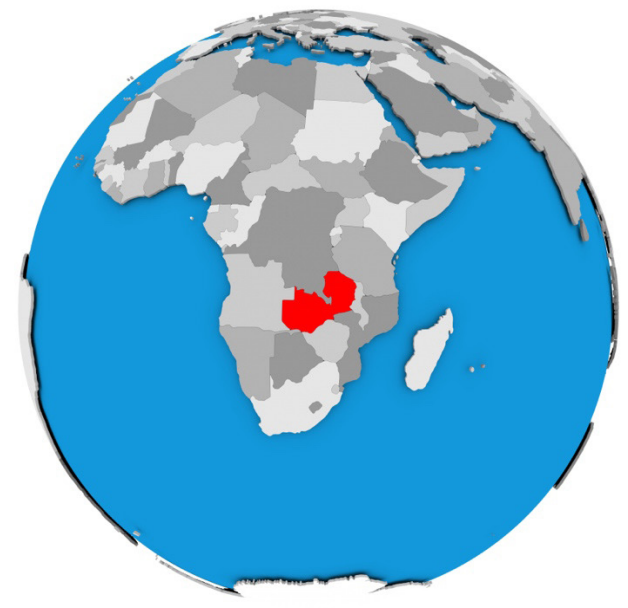

Figure 1. Location of Zambia

Zambia is in Southern Africa and is landlocked (Figure 1). Tanzania and Democratic Republic of the Congo (formerly Zaire) are on its northern borders, Malawi and Mozambique in the east, 
Zimbabwe, Botswana, and Namibia in the south, and Angola in the west. It measures 752,618 square kilometres. Zambia has 18.4 million people while New Zealand has 5.1 million people and a gross domestic product (current US\$) of US\$19.32 billion, while New Zealand's is $\$ 212.5$ billion (World Bank, 2020). Zambia is well endowed with natural resources, especially copper. It is ranked in development as a lower middle-income country. However, most of its citizens are worryingly poor:

... poverty has remained persistently high at 76.6 percent in rural areas, compared to 23.4 percent in urban areas. (Ministry of National Development Planning, 2017, p. 35)

There is high unemployment among youth, and the country is highly donor dependent and extremely indebted. Debt has reached US $\$ 14.48$ billion, over $60 \%$ of gross domestic product. Most of this is owed to China; US\$6.18 billion including unpaid interest (Africanews, 2021).

During the period 2006-2015, Gross Domestic Product (GDP) growth averaged 6.9 percent against a target of above 7 percent. During the FNDP period, GDP growth averaged 6.1 percent. GDP growth slowed down from 7.6 percent in 2012 to 2.9 percent in 2015. During the FNDP period, inflation averaged 11.4 percent (2006-2009), averaged 9.9 percent between 2011 and 2015 and in November 2016 to 8.8 percent. Zambia's stock of external debt has been rising since 2012. At the end of 2014, external debt stock was at US\$4.81 billion, representing 24.0 percent of GDP. In 2015, external debt was US\$6.41 billion, and as at September 2016 the external debt had reached US\$6.7 billion, representing 35 percent of GDP. (Ministry of National Development Planning, 2017, pp. 18-19)

It is within this context that this article first explores civil society in Zambia to set the scene for the growth of monitoring and evaluation 
(M\&E). Following this, evaluation challenges are described before suggestions are made for improving civil society's partnership in evaluation in Zambia. Finally, some lessons are drawn from Zambia's experiences for other nations' civil societies.

\section{Background of civil society in Zambia}

CIVICUS (2008) defines civil society as "the arena, outside of the family, the state, and the market, which is created by individual and collective actions, organisations and institutions to advance shared interests" (n.p.). Civil society in this southern part of Africa has its genesis in the evangelisation by European Christian missionaries' pre-colonialism and white settlers during colonialism.

Indigenous intellectuals in Northern Rhodesia (as Zambia was called before independence) started questioning the supremacy of the white minorities. These intellectuals were mostly government clerks, mission-educated church employees, miners, and storekeepers. They formed voluntary associations that were called welfare associations. They resembled British workers' associations of the 19th century. The first welfare association was formed in 1912. It was called the Mwenzo Welfare Society. Mwenzo was a protestant missionary station in Northern Rhodesia. It mainly aimed to be a link between the white colonialists led by the British South African Company (BSC) and the governed. African-led Christian churches were formed as a way of rejecting European missionary control. A charismatic indigenous evangelist, Lenshina, also formed her Lumpa sect. They copied the Afro-American-led churches. The US-based Watchtower sect that questioned the governance of chiefs and the colonial government also became popular and gained a major following in the northern part of Northern Rhodesia.

The associations mainly advocated for the lowering of tribal barriers, rapid Europeanisation by extending modern education to all, 
increasing industrial employment opportunities and lifting restrictions from career progressions for blacks, enhancing rural indigenous communities' access to improved agricultural techniques, improving water and sanitation facilities for indigenous communities, removing the movement restrictions and for permanent residency for blacks in urban settlements, stopping whites from having black concubines, mistreating them, and rejecting their multi-racial children, and restricting operating time and access to beer halls. This was to stop the devastating effects of mass-produced alcohol on black communities, especially on productivity, the emerging social challenges of prostitution, and spread of unknown before communicable diseases in indigenous communities.

Multi-ethnic welfare associations started being formed almost two decades later. The British government had taken over control of Northern Rhodesia in 1924 from BSC. Rapid urbanisation alongside rail lines had led to major tension between the majority locals and immigrant minority of whites and Asians. The multi-ethnic associations were formed beginning in the then capital of Northern Rhodesia, Livingstone, and then Ndola and Broken Hill in 1930. Later, they were established in Choma (1931) and in Luanshya (1932), the original mining town on the Copperbelt (Hooker, 1966). Unlike the Mwenzo association, they were very militant, concentrating on social and economic issues, rather than on political ones.

In 1933, the welfare associations united to form the United African Welfare Association. They planned to extend their presence into villages. However, the colonial government exerted a lot of pressure on the operations of welfare associations that they closed. Thus, the colonial government prevented the creation of a united country-wide organisation. However, several of them, including the Watchtower sect, were reported (unconfirmed) as having been involved in the 1935 Copperbelt riot. Long-festered resentments by 
locals against white minority rule exploded when the tax rate for black miners was increased (Rotberg, 1965). The Watchtower sect that was legally operating at that time was later banned.

Former priests and teachers of the Seventh Day Adventist Church in Southern Province helped form the first territory-wide nationalist party in 1937-the Northern Rhodesia African Congress. However, the colonial government refused to register it. Some of the former leaders of welfare associations were later to become leading members of unions and political parties of natives. Lessons from the operations of welfare associations helped locals in the formation of trade unions from the late 1940s. Civil servants, shop assistants, and truck drivers formed their own unions. The copper miners came up with the Group of 17. This was a tribally balanced team of miners that was selected to negotiate with the white mine owners for higher pay for their black employees. Miners came from most of the 73 ethnic groups of Zambia as well as from neighbouring Congo, Malawi, and Tanzania. This emerging multi-ethnicity and unity in fighting for common causes worried the mine owners and colonial government. They, therefore, restricted the stay of miners in urban settlements and forced workers to go back to their villages after their contracts ended. As most of the black miners resented this regulation, the emerging political movements in the colony found a lot of support among miners.

In 1946, the Northern Rhodesia Federation of Welfare Societies was formed. It was transformed in 1948 into the Northern Rhodesia Congress. This was to be registered by the colonial government as a political party (Momba \& Gadsden, 2013). Young militant blacks copying the militancy of Kamuzu Banda's party in Malawi formed the United National Independence Party (UNIP). It was UNIP that led Zambians to their independence from Britain on 24 October 1964. More non-government organisations (NGOs) were formed 
after independence because of the adverse effects of the global oil and financial crises of the 1970s.

Religious organisations still form part of current civil society and are most influential. For example, the Jesuits were central in the establishment of the Civil Society for Poverty Reduction (CSPR) in 2000 with its mission:

... to ensure that civil society effectively and meaningfully participates in the design, formulation and implementation of the National Development Plans and further monitor the National Development Plans to ensure government provides a means by which Zambia can effectively strategise on reducing the escalating levels of poverty. ${ }^{1}$

Zambia's treasury reserves got wiped out in 1971 because of its currency's link to the pound sterling that had drastically fallen (Njovu, 2019). Reliant on imports for many of its goods and services, the adverse effect of the drop in the value of the pound was that prices of goods rose beyond most of the citizens' reach. The government was unable to continue subsidising some social services. Government sought financial assistance from developed nations and the International Monetary Fund (IMF). The conditionality for accessing the loans and grants meant more hardships for the majority of citizens. However, the assumed improvements of the economy as a result of the loans did not come. Zambia ended up getting more foreign loans to sustain itself.

Later, a structural adjustment programme was embarked upon in 1983 (Simutanyi, 1996, p. 826) with the help of the international monetary financiers. However, the economic and social status of Zambians did not seem to improve. Highly indebted, Zambia then got some relief under the Highly Indebted Poor Countries programme of the IMF. The programme led to more involvement

1 http://www.csprzambia.org/about/who-we-are/ 
of the donor community in Zambia's economic and social sectors, including governance. The intervention policies, projects, and programmes that were implemented with the help of external donors had accountability components. These required assessment of adherence to financial regulations through financial audits. They also required assessment of adherence to the interventions goals and plans through M\&E.

Until the Paris Declaration on Aid Effectiveness (2005), there was a lot of fragmentation in aid delivery. "The main focus of the Paris Declaration is improving the effectiveness of aid through ownership, harmonisation, alignment, results and mutual accountability" (Chigunta \& Matshalaga, 2010, p. v). After the declaration, the donor community and the United Nations (UN) agencies started to support Zambia's efforts to build local capacity in M\&E. This was mainly translated by cooperating partners (CPs) as enhancing the capacity of civil society and government in project management and M\&E. In the Zambian context, CPs are foreign governments represented through their embassies and development aid agencies, UN agencies, international development financial institutions, and some private organisations. These had, or have, development agreements with the Zambian government to assist it in the democratising, economic, and social development of the country.

Civil society led by churches started to build their own M\&E capacity. UNICEF spearheaded the formation of a national evaluation association of M\&E professionals that helped civil society. The Civil Society for Poverty Reduction's (CSPR) Barometer Project and Society for Women against AIDs in Zambia started to perform independent M\&E of the government's budget disbursements. The Zambia Evaluation Association (ZEA) was formed in 2001. ZEA was a member of CSPR and led the coalition of civil society and government on national M\&E development. ZEA was instrumental 
in helping other members in establishing M\&E systems and formulating strategies. Co-operation between civil society and government on seeking alternatives to structural adjustment programmes led to formulation of the national poverty reduction strategies and the Fifth National Development Plan. M\&E was embedded in the Fifth National Development Plan (2006-2010) and it was to become a major feature of national planning. It also led to the formation of joint M\&E committees on major sectors; for example, the Governance Monitoring and Evaluation Committee (GMEC).

\section{National development planning}

The Zambian government, after independence and until the change of government in late 1991, based its social and economic development on national centralised plans. There were four national development plans during this period. The last one, the Fourth National Development Plan, was launched in 1989 and abandoned in 1991 after the reintroduction of multi-party politics. However, the country realised that, even in a free market economy, there was a need for national development planning. India is an example. The poverty level was worrying as it was dangerously high-68\% of the population in 2004 (Government of Zambia, 2006b) despite the structural adjustments and some favourable macro-economic statistics. Other worries were the lack of national policy for prioritising and co-ordinating national development, and unco-ordinated co-operation with the donor community and growing civil society. Therefore, the government reintroduced centralised development planning in 2002. The Poverty Reduction Strategy Paper (PRSP) 2002-2004 was worked on and then the Transitional Development Plan (2002-2005). The first 5-year plan of the post-1991 era was the FNDP. Afterwards, the government prepared the national long-term plan-Vision 2030 (Government of Zambia, 2006a). 


\section{Harmonisation and alignment}

The aid effectiveness debate had gained momentum in Zambia due to the failure of many major international interventions of the late 1970s and 1980s (for example, the structural adjustment programme). Zambia therefore took part in the international debates on aid effectiveness or harmonisation and alignment (H\&A). Like many developing countries, Zambia had been concerned about the varying conditionalities of developmental aid by the various donors. The interests of recipients of the assistance were in most cases not considered. It participated in the Monterrey Conference on Financing for Development (2002), the Rome Declaration on Harmonisation (2003), and the Marrakech Round Table on Managing for Development Results (2004).

The formation of the Harmonisation in Practice (HIP) initiative was in response to the Rome Declaration on Harmonisation. Seven donors (Demark, Finland, Ireland, the Netherlands, Norway, Sweden, and the United Kingdom) had come together to support it. However, there were many influential development partners that did not join. In April 2004, a Memorandum of Understanding (MoU) on Coordination and Harmonisation of GRZ/Donor Practices for Aid Effectiveness in Zambia was signed by the seven donors with the Zambian government.

Later, Germany, the World Bank, the UN mission in Zambia, Japan, Canada, France, Italy, the European Union, and the United States, appended their signatures to the MoU. Therefore, a new MoU was created and called the Wider Harmonisation in Practice (WHIP).

The HIP and WHIP initiatives were aligned to Zambia's longterm development vision (Vision 2030). In a drive for more ownership of the development aid initiative, the Ministry of Finance and National Planning published its Aid Policy and Strategy in June 2005. This was aimed at laying out terms and conditions that the 
government wished for in obtaining assistance from CPs to maximise the impact of developmental aid and achieve national plans. The WHIP initiative called for more CP support for accountability and transparency in governance; that is, support in strengthening the Office of the Auditor General and national M\&E systems. These were picked up later and included in the FNDP (2006-2010).

The FNDP identified national critical areas in which to seek funding from CPs. The CPs came up with their own policy document to address both the FNDP and Vison 2030; that is, the Joint Assistance Strategy for Zambia (JASZ (2007-2010)). This was the most harmonised strategy of CPs based on the Paris Declaration to address the developmental needs and priorities of Zambia as set out in the FNDP (Chigunta \& Matshalaga, 2010). However, there have been challenges in implementing the M\&E professional development and capacity building, as highlighted by Dr Francis Chigunta and Dr Neddy Matshalaga in their evaluation (2010, p. vii). For example:

- Some procedural and operational challenges on the harmonisation and alignment (H\&A) agenda. Though recognising the Paris Declaration's principles, some CPs still relied on home country systems, processes, and foreign policies that had not yet changed. Many CPs were not opening to accountability and transparency to the government and other local partners. There was also weakness of leadership in CPs and government agencies where they did not have the required capacity.

- Weaknesses in the government ownership of the development process and leadership of the H\&A agenda. Government was unable to be forceful in positioning itself on ownership and insisting that CPs took their rightful positions in the division of labour pertaining to assisting it to implement the FNDP. Despite the best intention 
of the Paris Declaration, the power and decision making effectively resided with donors. CPs had taken time to break from the habit of talking down to government. Most of the public servants, probably due to a colonial legacy or fear of losing funding to their programmes, operated as if they were not aware of the Paris Declaration principle of ownership and their own government's policy documents; the FNDP and the Aid Policy and Strategy.

- The non-inclusion of crucial cross-cutting issues, such as human rights, the environment, and HIVIAIDS. These crucial national issues were being treated separately and according to each CP's aid preference. A major weakness was that the H\&A process had relied on the implementation of the $2004 \mathrm{MoU}$ between the government and CPs and not on the Paris Declaration.

- The CPs had not performed well in joint missions. They had their own forum where they retrenched their positions. They were able, for instance, as a group, to introduce new conditionalities (for example, in the health sector where there were cases of misuse of donor funding). There was an agreement between the government and CPs on the division of labour pertaining to the FNDP and Vision 2030; The Joint Assistance Strategy for Zambia (2007-2010). CPs had been allocated areas of priorities in 20 development sectors. However, they had their own preferred areas of development assistance. Some groups were congested while others had few CPs.

- There were also challenges in harmonisation within the community of $C P s$, with some of the big donors having a tendency not to work as a team. There were emerging CPs such as China and Brazil that operated in isolation from the joint arrangement. An example is in the building of national M\&E capacity. The European Union and UN agencies were supporting one faction while the US agencies were supporting another, so Zambia ended up with two national 
professional M\&E bodies-ZEA and the M\&E Support Systems (MESSY). However, the African Evaluation Association urged for the merging of the two. This led to the creation of ZaMEA. CSPR was seen as a Jesuit-organised civic umbrella body for Zambian NGOs, so it had a rival umbrella NGO — the Zambia Governance Foundation, supported by CPs.

\section{Monitoring and evaluation (M\&E)}

$\mathrm{M} \& \mathrm{E}$ is a management function in development projects and programmes that are funded by external donors. This is due to accountability requirements on governments and charities to report to taxpayers and donors about the use of funding. Some NGOs have programmes that monitor and evaluate (for example, public policies and national plans). The Gender NGOs Coordinating Council (NGOCC) has programmes that focus on monitoring gender-related public policies, national plans, and programmes like the Police Victim Support Unit's implementation of the Anti-Gender Violence programme.

CSPR was doing its own independent government budget tracking. The Action for Transparency Project (A4T) had also embarked on its own budget tracking of the education and health sector involving citizens (Mumbuna, 2015). It was a joint project of Transparency International Zambia, Zambia Institute of Mass Communication, and the Fojo (Swiss) Media Institute. In addition, national-led governance evaluations are supposed to be carried out by GMEC. It was created in 2007 to monitor and evaluate the implementation of the governance chapter of FNDP. Its members were made up of government ministries and organisations (80\%) and representatives of civil society (20\%).

Bearing this context and the many players in the evaluation space in mind, the evaluation challenges for civil society in Zambia are 
canvassed next. Following on from this, the article concludes with some ideas for improving civil society's partnership role in M\&E.

\section{Evaluation challenges for civil society}

\section{Internal challenges}

Even with well-established M\&E systems, there have been many cases of intervention failures. Evaluations of civil society in Zambia are mainly externally driven. Although there is talk of respecting beneficiaries, participatory evaluations, and being culturally sensitive, the dissenting voices of beneficiaries are usually ignored. Many projects that have been evaluated and termed successful have ended up being failures after the donors pull out. This could be due to a linear approach in project design and inflexible M\&E log frames. The methodologies of evaluation are sometimes dictated by the commissioners who are also donors. Some evaluators try to please the wishes of donors that all interventions should be successful. They either end with conclusions that are hanging or leave out negative outcomes.

There is also a lack of the spirit of service in employees of some NGOs and development agencies. There are some employees who abuse their offices. This is particularly so in the health and social sectors. For example, a major management challenge to achieving programmes is due to financial abuse, despite M\&E practitioners being part of the organisation. A major umbrella NGO and main channel for external funding of HIV/AIDS and TB programmes and projects in Zambia ended up closing due to financial abuse, although there were $M \& E$ experts there. An umbrella protestant church association also had employees who were conniving with employees of a donor agency and issuing false evaluation reports.

There is also a lack of transparency in the commissioning of evaluations. This can be observed in the development of networks of 
evaluators that seem to be constantly commissioned by the same client. Other NGOs' executives commission their friends and relatives to carry out the evaluations.

Unlike the construction service where low standards of work can be visibly seen, it is not easy to ascertain the quality of evaluations. A building could collapse, a road will develop potholes shortly after construction, and there can be low quality of drugs in clinics where cases of corruption are involved. However, it is difficult to ascertain the quality of evaluations, especially when the reports are not publicly disseminated. There are no ethical guidelines about how commissioners and M\&E consultants should work together. Although the constitutions of national associations may have clauses on the expected standards of evaluations and disciplining members, there is no evidence that these have been enforced.

ZEA split into two shortly after being formed due to internal conflicts among its executive. Much of the unhappiness by some members leading to the split was the perception that only a few members of ZEA were securing work or being recommended by ZEA to commissioners who were approaching it. ZEA was also seen as seemingly benefiting those who were close to top officials in the Ministry of Finance. Most of the commissioning of $\mathrm{M} \& \mathrm{E}$ assignments for government projects and programmes was through the Ministry of Finance.

\section{Challenges of co-ordinating with government}

\section{Toxic relationships}

Civil society is supposed to be a helper that fills the development gap that can not be closed by government as a result of resource constraints. However, sometimes the relationship between the government and civil society is toxic. The government is usually sceptical of outputs from NGOs that they perceive as being used by external forces.

Each time the Auditor General's Office issues a report, Transparency 
International—Zambia will become very visible in mass media. It will express alarm at the level of abuses of public offices and demand from government action on protecting government revenue and assets. This ritual would be repeated the next year. However, during the rest of the year, there would be no monitoring of whether the government has prosecuted those who were cited as abusing their office or introduced new measures to deter abuse of offices. The current President (His Excellency Hakainde Hichilema) has campaigned and warned that abusers of public offices that are mentioned by the Office of the Auditor General will now be prosecuted.

In Zambia, most of the notable NGOs are established by external institutions and depend on external funding. Therefore, some Zambian civil society mirrors the interests of external funders.

\section{Constraints}

The main challenges for local NGOs are financial and technical constraints. They do not have a large membership base to be able to sustain themselves from members' subscriptions. Also, there are very few trained evaluators. Young emerging evaluators usually end up going to work abroad. There are, however, efforts by the Zambian government and some education institutions to train more Zambians in M\&E.

CSPR is an umbrella body of about 40 NGOs that mainly carry out poverty reduction programmes. Many of its members rely on external CPs. Without grants from external donors, it would be very difficult for them to carry out any advocacy programme and their survival could not be assured. When the Danish International Development Agency (DANIDA) closed its offices, some NGOs closed. The closure also affected the consortium of government institutions and civil society that were monitoring and evaluating the implementation of the FNDP. For example, the Governance Monitoring and Evaluation Committee (GMEC) based at the Ministry of Justice had to scale 
down its operations. GMEC was also adversely affected by the change in priorities of the German government in its disbursement of financial aid. This was almost at the same time that DANIDA was scaling down its operations in Zambia.

Some NGOs tend to not like highlighting their shortcomings. The final copy of an evaluation report may, therefore, not represent fairly the findings of the evaluator. This is usually in assignments commissioned by the NGOs themselves, or where the evaluators "flatter" the organisation and minimise any shortcomings to maintain the NGO as a client and their flow of work and income.

Although co-operation with the government has continued, civil society seems to be no longer playing a major role in national M\&E. This could be attributed to being too reliant on external funding and to the, sometimes, volatile relationship with government. The new national evaluation association, ZaMEA, that is supposed to lead civil society in evaluation is not leading the Seventh National Development (2017-2021) Plan's monitoring. The M\&E of the plan was spearheaded by the Office of the President under the former President Edgar C. Lungu. M\&E does not seem to feature under the functions of the current president. Even the national think tank, Zambia Institute for Policy Analysis and Research (ZIPAR) lacks independence as it is under the Ministry of Finance.

ZaMEA faces the common challenges of many members of Zambia's civil society. It is too dependent on a few major contributors to fund its operations. These tend to be mostly foreign donors. They are also unable to attract much local support for their ongoing survival. ZaMEA is also too weak financially to protect its practising members or fix minimum fees for local evaluators. Many commissioners will pay very high amounts to foreign consultants but apply an in-the-country evaluation fee structure, which is substantively lower for the same type of work. 


\section{Accountability and transparency in civil society}

There is inability to learn from the past and to avoid weak leadership and management. There is also inability to enhance service delivery for the benefit of the majority of members and the nation. Accountability and transparency are principles that civil society advocates for government to adhere but not by itself. Cases of abuse of offices are common in CSO just like in government.

Out of all the multilaterals [operating in Zambia], the Global Fund is the most vulnerable to abuse. It is dogged by conflicts of interest. We have millions of dollars going into the pockets of a few individuals. The entire CCM (Committee that disburses funds to NGOs applying for funding) should quit and new people should be appointed. Then we should change all of the PRs. (Zulu, 2010, p. 1)

\section{Ensuring no one is left behind}

Zambian evaluators and politicians talk of not leaving anyone behind. However, most people who need to have M\&E skills to enhance their participation in national and local governance are not empowered by civil society with the skills needed (for example, score carding of their elected leaders). To reach most people, civil society would have to shift its focus to people it has not been reaching presently.

ZaMEA needs to broaden its reach and better balance the needs of members and citizens with the requirements of donors and government.

Citizens require timely help to understand issues of national development programmes and plans. ZaMEA does not presently issue public briefs on national development that would be of help to ordinary citizens. CSPR at one time had tried to simplify the technical jargon of national plans so that they would be easier to understand by ordinary citizens. The FNDP was published in local languages by the Ministry of Finance, but the practice was not continued when 
publishing the next plans. ZaMEA should be spearheading efforts to make government policies and major evaluative national policy and plans documents easily accessible and understandable by most Zambians. Most Zambians speak indigenous languages and not English. Not all citizens are able to benefit from the pool of M\&E experts in civil society. Much of civil society has concentrated their activities mainly in Lusaka or major towns where they are easily visible to foreign embassies and development agencies.

In Zambian civil society there has also been a lack of innovation in M\&E and advocacy for indigenous or "Made in Africa" evaluation methodologies. Many of the commissioners dictate the methodologies that are used in monitoring and evaluating their projects and programmes. For instance, those funded by the US government are likely to insist on using impact evaluation methodologies. Although there are talks of being culturally sensitive and allowing for participatory evaluations by commissioners and evaluators, the power of who pays for the evaluations rules the processes. The beneficiaries are usually too poor and the evaluators may not voice concerns due to their reliance on these evaluation contracts for their livelihood.

\section{Improving civil society's partnership in evaluation}

Zambian civil society has been very active in many sectors of national social and economic development. Evaluative evidence provided by civil society continues to play a major role in the advocacy work of civil society. Civil society in Zambia has, in turn, played a major role in developing national evaluation capacity. Now that the Ministry of National Development Planning has been reduced to a department of the Ministry of Finance, civil society needs to enhance its role in building national evaluation capacity.

However, civil society currently faces challenges. These are mainly of sustainability, lack of public support, and sometimes suspicions 
from government. In addition, the nation is currently facing serious social and economic challenges, especially because of the adverse effects of COVID-19. It is time for civil society to become the alternative to government for solace of the most vulnerable people. Civil society has therefore to enhance its ability to be the watchdog of the nation and be the voice of the majority of voiceless citizens.

CSPR used to lead the way by organising its members to come together to be effective watchdogs of the people in national governance. ZEA members were visible in civil society's co-operation with government to develop national M\&E systems and capacity. Now it is the Gender NGOs Coordinating Council that seems to be leading in ensuring that its members' capacity to monitor and evaluate government's gender-related policies, plans, and programmes is enhanced. It is also helping its members to develop M\&E systems to provide much needed objective evidence for use in advocacy programmes. ZaMEA has been currently active in building its members' technical skills. It has also been trying to work closely with the government and donor agencies in building national evaluation capacity (Njovu, 2018).

As the donor community is facing the same financial and social challenges because of the coronavirus pandemic, it likely that Zambian civil society will further face challenges of sustainability. Those NGOs that largely depend on foreign donations must quickly find alternative ways of mobilising resources. When most Zambians begin to perceive that NGOs are not serving the interests of external forces but are instead working for the betterment of Zambia, it likely that more of them will participate in NGO activities and contribute to their sustenance.

Civil society also needs to start partnering and pooling resources to enhance their generation of evaluative evidence for advocacy. NGOs that are leaders in their sectors can be supported by others to commission evaluation that could be used by other members of civil 
society for advocacy; for example, NGOCC has been in the forefront for decades on gender-related issues. Evaluators can also help increase the participation of citizens in civic duties and make civil society a highly effective advocate for most citizens. In cases where NGOs may not be able to afford M\&E experts, they can offer pro bono services.

\section{Lessons for other nations' civil societies}

\section{Grow national civil society using your own resources}

The adverse social and economic factors that led to the formation of civil society in Zambia are prevalent in many countries. We have seen the growth of global movements like Black Lives Matter and Me Too. Many successful NGOs depend on volunteers with the passion to change the status of their communities, nations, and world to a better level. However, unlike in the developed nations, Zambian NGOs and many other NGOs in developing nations very much depend on external donors' assistance. They carry out valuable national programmes, especially those aimed to reduce poverty. They also offer checks and balances to government and ensure good governance in the country. This is very important as there are major weaknesses in our democratic institutions and public media. Much of this is done through M\&E that forms the backbone of their advocacy programmes. The COVID-19 pandemic and ensuing economic downturn has, however, had very adverse effects on the Zambian civil society as well as government. They have been exposed to their vulnerability to external shocks especially reliance on external donors. Therefore, both have not been able to adequately serve their constituents. The Ministry of National Development Planning has been scrapped and turned into a department of the Ministry of Finance. This is leading to uncertainty on the development of national evaluation capacity. 


\section{Need for good leadership}

There is also need for introspection. Zambian civil society has become a major employer as formal employment sectors are facing challenges. Much of civil society in Zambia is seen as a tool of politicians or donors. There have also been many scandals involving abuse of members' and donors' funds in Zambian civil society. These have affected its credibility. There is a need to have credible managers in civil society if it is to attract the needed public participation in its activities. Civic bodies across the world need to have this as a priority and ensure that they employ credible staff.

\section{Build capacity at the grass root level}

The world is crying for good governance in many states as can be seen by political conflicts being experienced in some nations. Good governance can only be sustained if the majority of people are empowered to exercise their civic rights. The M\&E profession has a duty to ensure that no one is left behind in development and governance by empowering people who are mostly affected by public services. By contrast, the emphasis of CPs in Zambia's national evaluation capacity development has been in building the capacity of NGOs and government agencies. This has been through sponsorship of M\&E workshops, conferences, and courses. While this is good, only a few people end up being empowered.

Civil society in Zambia meanwhile concentrates its operations in urban areas and especially in the capital for visibility. While the presence of donors' and government offices is vital for their operations, much of their services are required by the vulnerable people in remote rural areas or economically disadvantaged townships. However, what has been realised recently during the COVID-19 pandemic and following the overwhelming victory of the long-time opposition party in the August 2021 general elections, is that both 
civil society and government have been missing it. That is, that the majority of ordinary people's perceptions matter on national development. The previous ruling party had ignored public outcries on the high level of abuse of office by politicians revealed by mass media and the Office of the Auditor General, poor public service delivery, unemployment, violence by its cadres, and political intolerance. It is mostly the ordinary youth who are ignored by public systems and are adversely affected by unemployment who booted out the previous government. This was despite the favourable election polls forecast by highly qualified researchers for the ruling party.

However, the lesson for the world is that it should not take every 5 or 20 years for the public to sack an underperforming politician or public servant. Civil society should be able to assist citizens to effectively participate in governance between general elections. One way to do this is through empowering most citizens to perform M\&E (for example, score carding). Once most citizens realise the benefit of being empowered, they will gladly become members of civil society and volunteer to raise the much-needed funds for operations.

\section{Concluding remarks}

The growth of civil society in Zambia has underpinned many important changes in the country's recent history. A challenge now is about how to strengthen the capacity of civil society organisations to produce monitoring and evaluative evidence that holds government and international partners to account for the prosperity and wellbeing of the people of Zambia. Doing this in a way that is also in partnership with the people will also help ensure that civil society is seen as legitimate, and is working with them and for them. 


\section{List of abbreviations}

A4T..................Action for Transparency Project

BSC ................ British South African Company

CIVICUS .......Global alliance of civil society organisations

CP.................... Cooperating partner

CSPR ................Civil Society for Poverty Reduction

DANIDA ..........Danish International Development Agency

FNDP ...............Fifth National Development Plan

GDP ...............Gross domestic product

GMEC..............Governance Monitoring and Evaluation Committee

H\&A ...............Harmonisation and alignment

HIP ..................Harmonisation in practice

IMF .................International Monetary Fund

$M \& E$................Monitoring and evaluation

MESSY .............Monitoring and Evaluation Support Systems

$\mathrm{MoU}$.................Memorandum of understanding

NGO .................Non-government organisation

NGOCC..........Gender NGOs Coordinating Council

WHIP .............. Wider harmonisation in practice

ZaMEA ...........Zambia Monitoring and Evaluation Association

ZEA .................Zambian Evaluation Association

ZIPAR .............Zambia Institute for Policy Analysis and Research

\section{References}

Africanews. (2021). Zambia announces an increase in

foreign debt. https://www.africanews.com/2021/10/08/

zambia-announces-an-increase-in-foreign-debt/

Chigunta, F., \& Matshalaga, N. (2010). Evaluation of the implementation of the Paris Declaration in Zambia. Final Report Phase One. https://www. oecd.org/dac/evaluation/dcdndep/44549817.pdf

CIVICUS. (2008). Assessing the state of civil society: A toolkit for the CIVICUS 
Civil Society Index (CSI). http://www.civicus.org

Government of Zambia. (2006a). Vision 2030-A prosperous middle-income nation by 2030. Author.

Government of Zambia. (2006b). Fifth national development plan 20062010. Author.

Hooker, J. R. (1966). Welfare associations and other instruments of accommodation in the Rhodesias between the world wars. Comparative Studies in Society and History, 9(1), 51-63. https://doi.org/10.1017/ S0010417500004345

Ministry of National Development Planning. (2017). Seventh national development plan, 2017-21. Author.

Momba, J. C., \& Gadsden, F. (2013). Zambia: Nonviolent strategies against colonialism, 1900s-1960s. In M. Bartkowski (Ed.), Recovering nonviolent history: Civil resistance in liberation struggles (pp. 71-80). Lynne Rienner Publishers.

Mumbuna, N. (2015, March 7). Blow whistle on corruption-A4T, Times of Zambia.

Njovu, J. T. (2018). Zambia: The SDGs and developing national evaluation capacities. In People, planet and progress in the SDG era: Proceedings from the National Evaluation Capacities Conference 2017 (pp. 140-146). Independent Evaluation Office of UNDP.

Njovu, J. T. (2019). How it all began: Responses to letter to my children. SOTRANE.

Rotberg, R. I. (1965). The rise of nationalism in Central Africa: The making of Malawi and Zambia, 1873-1964. Harvard University Press.

Simutanyi, N. (1996). The politics of structural adjustment in Zambia. Third World Quarterly, 17(4), 825-839. https://doi. org/10.1080/01436599615407

World Bank. (2020). World Bank open data. https:/data.worldbank.org/ Zulu, W. (2010). The global fund in Zambia is vulnerable to abuse. https:// www.aidspan.org/en/c/article/879 


\section{The author}

John T. Njovu is an author, independent consultant, former chairperson of the Zambia Evaluation Association, former treasurer of the African Evaluation Association, and founder member of the EvalIndigenous Network.

Email: njovujt@gmail.com 